\title{
GENETIC ANALYSIS AND DISTRIBUTION OF PORCINE PARVOVIRUSES DETECTED IN THE ORGANS OF WILD BOARS IN SERBIA
}

\author{
NIŠAVIĆ Jakov ${ }^{1}$, MILIĆ Nenad ${ }^{1}$, RADALJ Andrea ${ }^{1 *}$, KRNJAIĆ Dejan ${ }^{1}$, MILIĆEVIĆ \\ Dragan $^{2}$, KNEŽEVIĆ Aleksandra ${ }^{3}$, RADOJIČIĆ Marina ${ }^{1}$, OBRENOVIĆ Sonja ${ }^{4}$, \\ ĆOSIĆ Milivoje ${ }^{5}$, TEŠOVIĆ Bojana ${ }^{6}$, BENKOVIĆ Damir ${ }^{7}$, ŽIVULJ Aleksandar ${ }^{8}$
}

\begin{abstract}
${ }^{1}$ Department of Microbiology, Faculty of Veterinary Medicine, University of Belgrade, Belgrade, Serbia; ${ }^{2}$ Institute of Meat Hygiene and Technology, Belgrade, Serbia; ${ }^{3}$ Virology Department, Institute of Microbiology and Immunology, Faculty of Medicine, University of Belgrade, Belgrade, Serbia; ${ }^{4}$ Department of Infectious Animals Diseases and Diseases of Bees, Faculty of Veterinary Medicine, University of Belgrade, Belgrade, Serbia; ${ }^{5}$ Department of Animal Husbandary, Faculty of Agriculture University of Bijeljina, Bosnia and Herzegovina; 'Veterinary Specialized Institute „Kraljevo“, Kraljevo, Serbia; ${ }^{7}$ Veterinary Specialized Institute „Sombor“, Sombor, Serbia; ${ }^{8}$ Veterinary Specialized Institute "Pančevo", Pančevo, Serbia
\end{abstract}

(Received 22 July 2020, Accepted 12 January 2021)

Porcine parvoviruses (PPVs) are diverse and persistently evolving viruses found in domestic pigs and wild boars. Porcine parvovirus 1 (PPV1) causes reproductive problems in adult animals, although the veterinary relevance of PPV2, PPV3, and PPV4 has not been clarified. The detection and sequence analysis of PPVs circulating in wild boar populations in Serbia was performed to determine their phylogenetic relationships and prevalence in 122 organ samples collected during 2018. The DNA of PPV1, PPV2, and PPV3 was detected in 56.6\% of the examined samples, whilst PPV4 was not identified. Overall, PPV3 was the most prevalent in $69.6 \%$ of the positive samples, followed by PPV1 in $63.8 \%$, and PPV2 in $21.7 \%$ samples. Single infections were more common, although concurrent infections were confirmed in $34.8 \%$ samples for two, and $10.1 \%$ samples for three viruses. Sequence analysis of wild boar PPV1 showed no significant nucleotide differences from domestic pig PPV1 strains detected in Europe and the USA, however separate clustering from strains from China and the NADL-2 strain was demonstrated. Examination of the selected PPV2 sequences might suggest a certain geographical distribution of genetically diverse PPV2 strains considering high similarities to the strains from neighboring countries, and variability in comparison with other reported PPV2 sequences from different parts of the world. Wild boar PPV3 sequences clustered separately from most of the strains detected in wild boars, as well as the original porcine hokovirus strain. It is further noted that genetically different PPV3 strains circulate amongst Serbian domestic pigs and wild boars.

Keywords: PPV1, PPV2, PPV3, wild boar, DNA sequencing

*Corresponding author: e-mail: andrea.zoric@vet.bg.ac.rs 


\section{INTRODUCTION}

Porcine parvovirus (PPV) is classified in the genus Parvovirus, Parvoviridae family. It causes infection in pigs and Eurasian wild boars leading to reproductive losses characterized by stillbirths, mummification, embryonic death, and infertility [1-3]. Parvoviruses are small non-enveloped viruses, with a linear, non-segmented, singlestranded DNA genome of about 5000 bases containing two major open reading frames (ORFs), namely ORF1 and ORF2 [1]. The non-structural proteins (NS) are coded by ORF1 and have a role in viral replication, whilst ORF2 codes for structural VP proteins which form the icosahedral capsid [1]. The shedding of PPV occurs through feces and other secretions of diseased animals in the acute phase of infection, however, one of the main transmission factors lies in its resistance in the environment and consequential spread through fomites [2-4].

As a result of modern molecular diagnostic approaches, novel porcine parvoviruses (PPVs) have been consecutively discovered around the world, therefore the classical porcine parvovirus is specified as porcine parvovirus 1 or PPV1 in newer literature [2,3,5-7]. Porcine parvovirus 2 (PPV2) was accidentally discovered in Myanmar and later described in many countries around the world including Hungary, Serbia and Croatia [8-12]. Another novel porcine parvovirus with a worldwide distribution is porcine parvovirus 3 (PPV3) which was first found in Hong Kong and initially named porcine hokovirus on that principle. However, it is currently appointed to the genus Tetraparvovirus because of its relatedness to human parvovirus 4 [1,13-15]. Porcine parvovirus identified in the lung lavage of a diseased pig co-infected with porcine circovirus 2 was denominated as porcine parvovirus 4 (PPV4) and did not cluster with the three previously identified porcine parvoviruses [13]. Since 2010, PPV4 was detected in many countries including Serbia [9-11,16]. More recently, novel porcine parvovirus types 5, 6, and 7 (PPV5, PPV6, and PPV7) have been detected, but still remain unclassified [1,17-19]. Even though other novel PPVs are increasingly detected in pigs worldwide, their clinical significance and transmission routes have not been elucidated, whilst high prevalence in clinically healthy animals might imply their commensal nature $[3,7,10,20,21]$.

In Serbia, to this date, porcine parvoviruses have been investigated in domestic swine, and in contrast to some neighboring countries, there is limited knowledge on their genetic characteristics, distribution and impact, especially on wild boar populations [9,22-24]. Porcine parvoviruses are actively evolving and diverse viruses that are currently under extensive research considering that some are being grouped with human parvoviruses, and the information is still scarce on their veterinary relevance $[5,7,9,15,25]$. Wild boars are very interesting models for these investigations since wildlife represents a potential reservoir for the spread of genetically altered strains of known viruses. Having that in mind, this study aimed to describe the presence of different porcine parvoviruses in the samples originating from wild boars in Serbia for 
the first time, as well as to elucidate their phylogenetic relationships and prevalence in sampled tissues.

\section{MATERIAL AND METHODS}

\section{Ethical approval}

The conducted research is not related to the use of animals.

\section{Samples and DNA extraction}

Tissue samples from 63 shot free-living wild boars were collected from August to November 2018. The animals originated from the South Banat District, i.e. municipalities of Pančevo, Bela Crkva, Plandište, Vršac, and Alibunar. The samples were collected in agreement with the local hunting organizations. In total, this examination involved 122 tissue samples: 61 samples of spleen, 43 tonsil samples, and 18 lymph node samples. The specimens were immersed into $2 \mathrm{ml}$ of minimum essential medium (MEM, Capricorn Scientific, Germany) with 2\% fetal calf serum (FBS-12A, Capricorn Scientific, Germany) supplemented with antibiotics and transported to the laboratory on ice. All organ samples were homogenized in phosphate buffered saline (PBS 7.2) and centrifuged for $10 \mathrm{~min}$ at 5000 RPM. Deoxyribonucleic acid (DNA) was extracted from the cell debris using GeneJET Genomic DNA Purification Kit (Thermo Scientific, USA) according to the manufacturer's instructions. The extracted DNA was stored at $-20^{\circ} \mathrm{C}$ pending testing.

\section{Polymerase chain reaction}

Specific oligonucleotide primers and polymerase chain reaction (PCR) protocol for the detection of PPV1 were previously described [26]. The amplicon size of $330 \mathrm{bp}$ corresponding to the gene encoding the non-structural protein 1 (NS1) visualized using $1.5 \%$ agarose gel electrophoresis was considered positive. The detection of PPV2, PPV3, and PPV4 was confirmed by the presence of 279 bp, 392 bp, and 284 bp bands, respectively, according to Csagola et al. [10]. The specified amplicon sizes corresponded to their respective capsid protein encoding genes, i.e. VP1 genes. Internal laboratory reference strains of PPV1, PPV2, PPV3, and PPV4 belonging to The Department of Microbiology, Faculty of Veterinary Medicine, Belgrade University that were previously confirmed by sequencing were used as positive controls.

\section{Sequencing}

The obtained positive PCR products were sequenced using oligonucleotide primers applied for PCR. In order to obtain partial nucleotide sequences of the NS1 gene of PPV1 and VP1 genes of PPV2 and PPV3, the PCR products were purified with QIA quick Purification Kit (Qiagen, Valencia, CA, USA). The purified PCR 
products were then sequenced with Big Dye Terminator Cycle Sequencing Kit (PE Applied Biosystems, Foster City, CA, USA). Direct sequencing of PPV1, PPV2, and PPV3 detected in this examination was performed by Sanger sequencing method. Sequencing reactions were analyzed on the ABI Prism 310 Genetic Analyser (Applied Biosystems, USA). Subsequently, the obtained nucleotide sequences were aligned and compared with analogous virus sequences available in the GenBank database using BLAST software (http://www.ncbi.nlm.nih.gov/BLAST). Evolutionary analyses were conducted in MEGA 7 software. The phylogenetic trees were constructed using Maximum Likelihood algorithm with 1000 bootstrap replicates. The evolutionary distances were computed using Maximum Composite Likelihood method.

\section{RESULTS}

\section{Detection of porcine parvoviruses 1,2 , and 3}

Out of 122 organ samples, 69 were positive for the presence of DNA of one or more porcine parvoviruses $(56.6 \%)$. Overall, porcine parvovirus DNA was detected in the tissues of 34 out of 63 examined animals (54\%). Out of 69 positive samples, 44 were positive for the presence of PPV1 DNA (63.8\%), 15 for PPV2 (21.7\%), and 48 for PPV3 (69.6\%), whilst PPV4 was not detected. Infection with one PPV type was found in 38 samples $(55.1 \%)$, i.e. the DNA of single viruses was determined in 15 (21.7\%), 2 (2.9\%), and 21 (30.4\%) samples for PPV1, PPV2, and PPV3 respectively. Moreover, the presence of co-infections with multiple PPVs was also verified in 7 $(10.1 \%)$ samples for all three viruses and $24(34.8 \%)$ samples for two viruses. Most of the co-infections were by PPV1 and PPV3, followed by PPV1 and 2, and PPV2 and 3 (Table 1).

Table 1. Results of the detection of porcine parvovirus DNA in different organ samples

\begin{tabular}{lccccccc}
\hline Samples & PPV1 & PPV2 & PPV3 & PPV1/2 & PPV1/3 & PPV2/3 & PPV1/2/3 \\
\hline \multirow{2}{*}{ Spleen } & 21 & 7 & 23 & 2 & 9 & 1 & 3 \\
& $(63.6 \%)$ & $(21.2 \%)$ & $(69.7 \%)$ & $(6.1 \%)$ & $(27.3 \%)$ & $(3 \%)$ & $(9.1 \%)$ \\
Tonsils & 15 & 7 & 16 & 2 & 3 & 1 & 3 \\
& $(65.2 \%)$ & $(30.4 \%)$ & $(69.5 \%)$ & $(8.7 \%)$ & $(13 \%)$ & $(4.4 \%)$ & $(13 \%)$ \\
Lymph & 8 & 1 & 9 & $/$ & 3 & $/$ & 1 \\
nodes & $(61.5 \%)$ & $(7.7 \%)$ & $(69.2 \%)$ & $/$ & $(23.1 \%)$ & $/$ & $(7.7 \%)$ \\
Total & 44 & 15 & 48 & 4 & 18 & 2 & 7 \\
\hline
\end{tabular}

PPV1 - porcine parvovirus 1; PPV2 - porcine parvovirus 2; PPV3 - porcine parvovirus 3; PPV1/2 porcine parvovirus 1 and 2 co-infection; PPV1/3 - porcine parvovirus 1 and 3 co-infection; PPV2/3 - porcine parvovirus 2 and 3 co-infection; PPV1/2/3 - porcine parvovirus 1, 2, and 3 co-infection.

Amongst the examined samples, the highest percentage of lymph nodes was positive $(13 / 18$ or $72.2 \%)$ followed by spleen samples $(33 / 61$ or $54.1 \%)$ and tonsils $(23 / 43$ or 
$53.5 \%$ ). Virus prevalence in individual organ samples was variable. The distribution of viral DNA among different positive samples of examined organs is presented in Table 1. Out of the positive organ samples, co-infections with two or three PPVs were present in $45.5 \%$ samples of spleen, $39.1 \%$ tonsils, and $30.8 \%$ of lymph nodes.

The distribution of sampled wild boars in South Banat District showing the ratio of positive and negative animals within municipalities is presented in Figure 1.

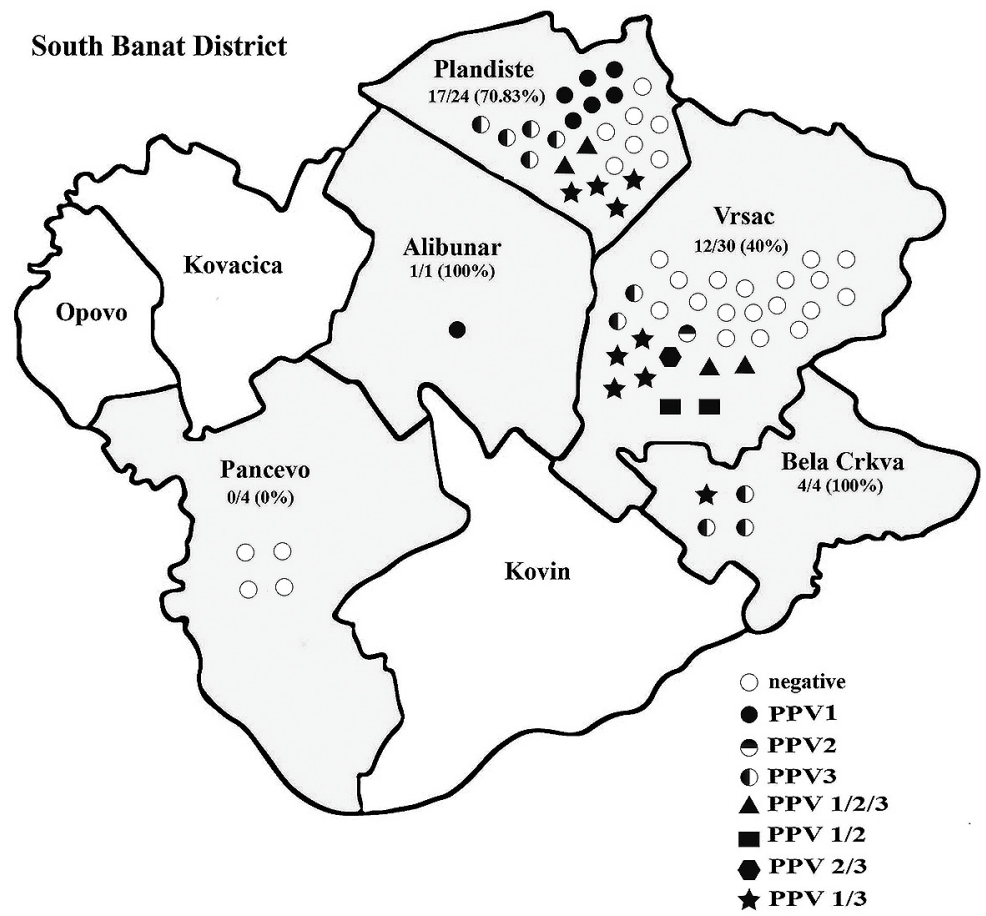

Figure 1. The distribution of positive and negative samples originating from wild boars from different municipalities within the South Banat District. The municipalities included in the study are colored grey and each symbol represents one animal. The symbols denote whether the animal was negative or positive for the presence of one or more parvoviruses.

\section{Porcine parvovirus 1,2 , and 3 sequence analysis and phylogeny}

The selected sequences of PPV1, PPV2, and PPV3 used in this study were submitted to GenBank and the assigned accession numbers for each sequence are provided in Table 2.

The results of the sequence analysis of partial NS1 gene of three selected wild boar PPV1 strains from Serbia (PPV1_3051, PPV1_3196, and PPV1_3795) demonstrated that they were 99 to $100 \%$ similar amongst each other as well as mostly with domestic pig strains from Europe and the USA, grouping together on the phylogenetic tree (Figure 2). The examined Serbian strains clustered separately from PPV1 strains 
from China (DQ675456, HM989009, JQ710890, and AY583318) as well as from the NADL-2 strain with whom they shared $98 \%$ nucleotide similarity.

Table 2. Details of the selected sequences used in this study

\begin{tabular}{ll}
\hline Name & GenBank accession $\mathbf{n}^{\mathbf{0}}$ \\
\hline PPV1_3051 & MN984630 \\
\hline PPV1_3196 & MN984631 \\
\hline PPV1_3795 & MN984632 \\
\hline PPV2_3698 & MN984633 \\
\hline PPV2_3702 & MN984634 \\
\hline PPV2_3731 & MN984636 \\
\hline PPV2_3743 & MN984637 \\
\hline PPV2_3794 & MN984638 \\
PPV3_2935 & MN984639 \\
\hline PPV3_3263 & MN984640 \\
PPV3_3341 & MN984641 \\
\hline PPV3_3373 & MN984642 \\
\hline PPV3_3731 & MN984643 \\
\hline PPV3_3373_1 & MN984644 \\
\hline PPV3_3730 & MN991299 \\
\hline PPV3_3734 & MN991300 \\
\hline
\end{tabular}

Partial VP1 gene sequences of the selected wild boar PPV2 strains from Serbia (PPV2_3702, PPV2_3794, PPV2_3743, PPV2_3731, PPV2_3728, and PPV2_3698) were 98 to $100 \%$ similar with each other, as well as with other domestic pig strains from Serbia and surrounding European countries including Croatia and Hungary, as well as with a wild boar PPV2 strain from Romania. Furthermore, the analyzed Serbian strains shared 97 to 98\% similarity with the original PPV2 strain from Myanmar (AB076669). Nucleotide similarities of Serbian PPV2 strains were lower when compared to analogous sequences of PPV2 strains originating from South African domestic pigs (94 to 97\%), also when analyzed with strains from China, Brazil, and the USA, their identities ranged from 97 to 98\%. The selected Serbian wild boar PPV2 sequences clustered with strains from both wild boars and domestic pigs from Serbia, Croatia, Hungary, and Romania, as well as with the original strain from Myanmar. However, clustering separately from the strains from Brazil, China, USA, and South Africa is visible on the phylogenetic tree (Figure 3).

Phylogenetic analysis of eight selected Serbian wild boar PPV3 strains (PPV3_3734, PPV3_3731, PPV3_3730, PPV3_3373_1, PPV3_3373, PPV3_3341, PPV3_3263, and 
PPV3_2935) demonstrated high similarities and clustering with domestic pig strains from Croatia, Romania, and Germany, as well as a wild boar strain from Slovakia (KP768520). All above mentioned PPV3 strains were 99 to 100\% similar. Furthermore, the examined Serbian PPV3 strains in this study clustered separately from analogous domestic pig strains from Hungary and Serbia, as well as wild boar strains from Germany and Romania while sharing 98-99\% nucleotide similarities. Moreover, the examined strains in this study were also separated from the original porcine hokovirus strain (EU200674) to whom they were 98 to 99\% similar (Figure 4).

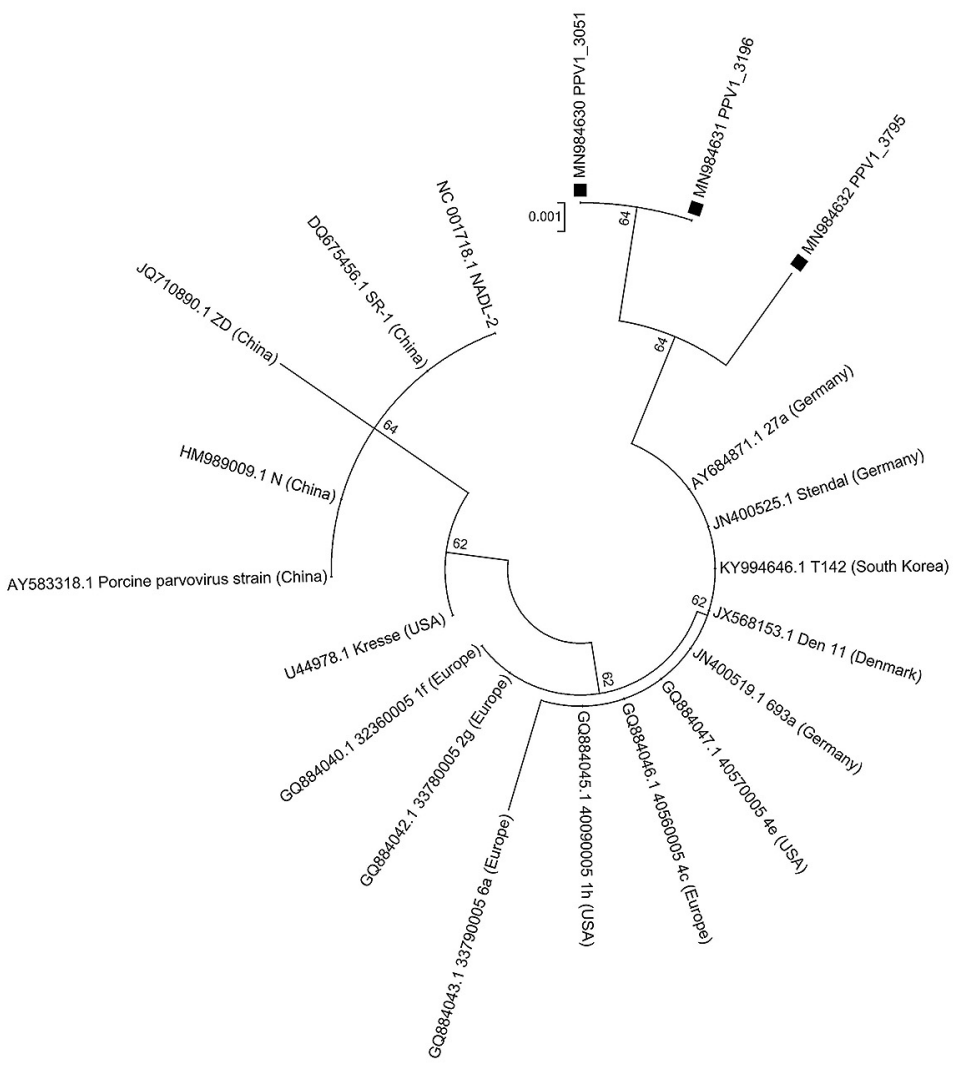

Figure 2. Phylogenetic tree constructed from 249 long partial NS1 gene nucleotide sequences of wild boar PPV1 strains and reference PPV1 strains obtained from NCBI GenBank. The tree was constructed using Maximum Likelihood algorithm with 1000 bootstrap replicates (using MEGA version 7). Black squares indicate the selected Serbian wild boar sequences. 


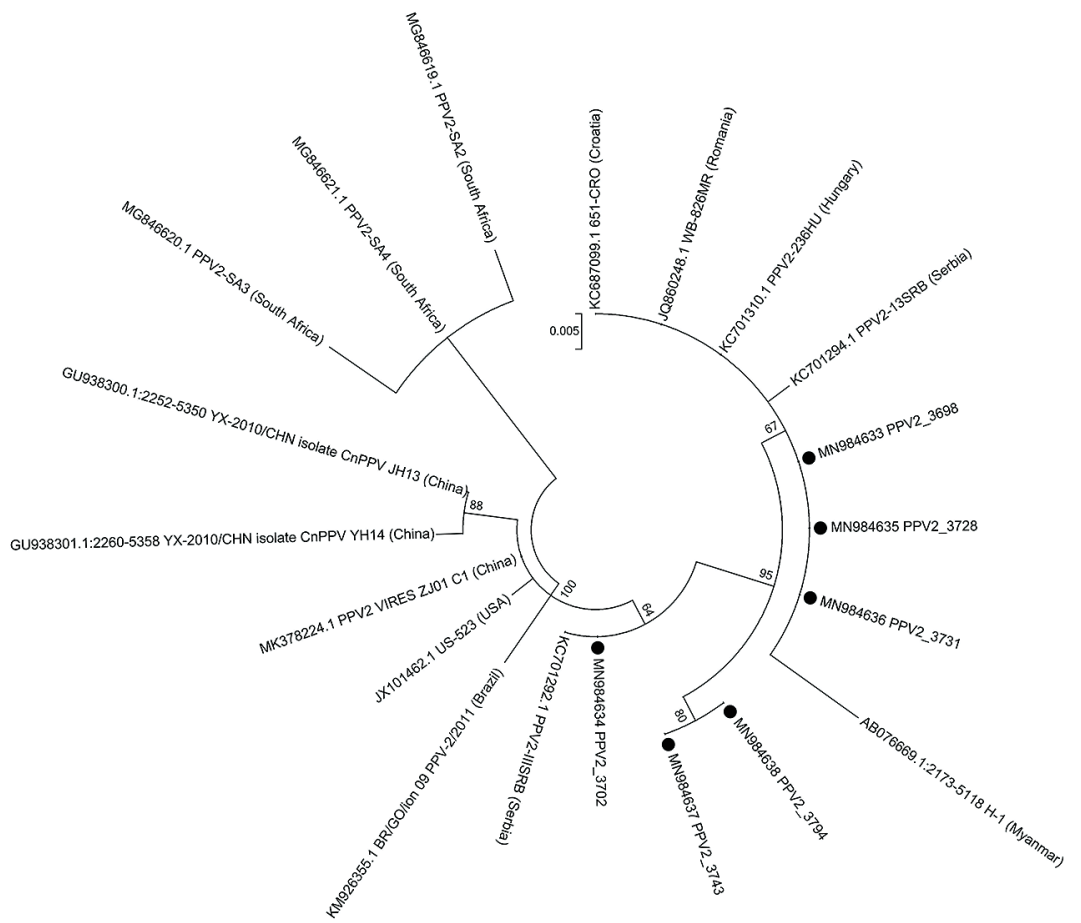

Figure 3. Phylogenetic tree constructed from 262 long partial VP1 gene nucleotide sequences of wild boar PPV2 strains and reference PPV2 strains obtained from NCBI GenBank. The tree was constructed using Maximum Likelihood algorithm with 1000 bootstrap replicates (using MEGA version 7). Black dots indicate the selected Serbian wild boar sequences

\section{DISCUSSION}

In this study, $56.6 \%$ of the examined samples were positive for the presence of one or more porcine parvoviruses, out of which $55.1 \%$ represented the DNA of single viruses and the rest was appointed to co-infections with two or three PPVs. Single infection was the most prevalent in wild boars in Romania, found in $54.1 \%$ of the samples [5]. Differently, the presence of co-infections with more than three PPVs in over $60 \%$ of the examined tonsil samples was reported [27]. Our results are also comparable to a study conducted in the USA showing infection with one PPV type in $75.3 \%$ of all PPV positive samples with $19.4 \%$ of samples being infected with two PPV types, and $4.3 \%$ positive for three PPV types [16]. The highest co-infection rates in our study were for PPV1 and PPV3, followed by lower rates for PPV2/3 and PPV1/2. Similarly, the second most prevalent type of infection in wild boars was by PPV2 and PPV3 [5].

The detection rate of PPV1 in our study was $63.8 \%$ which is in correlation with other studies performed on domestic pigs in Germany and Thailand [27,28]. Regarding the available data concerning PPV1 prevalence in samples from wild boars, results from 


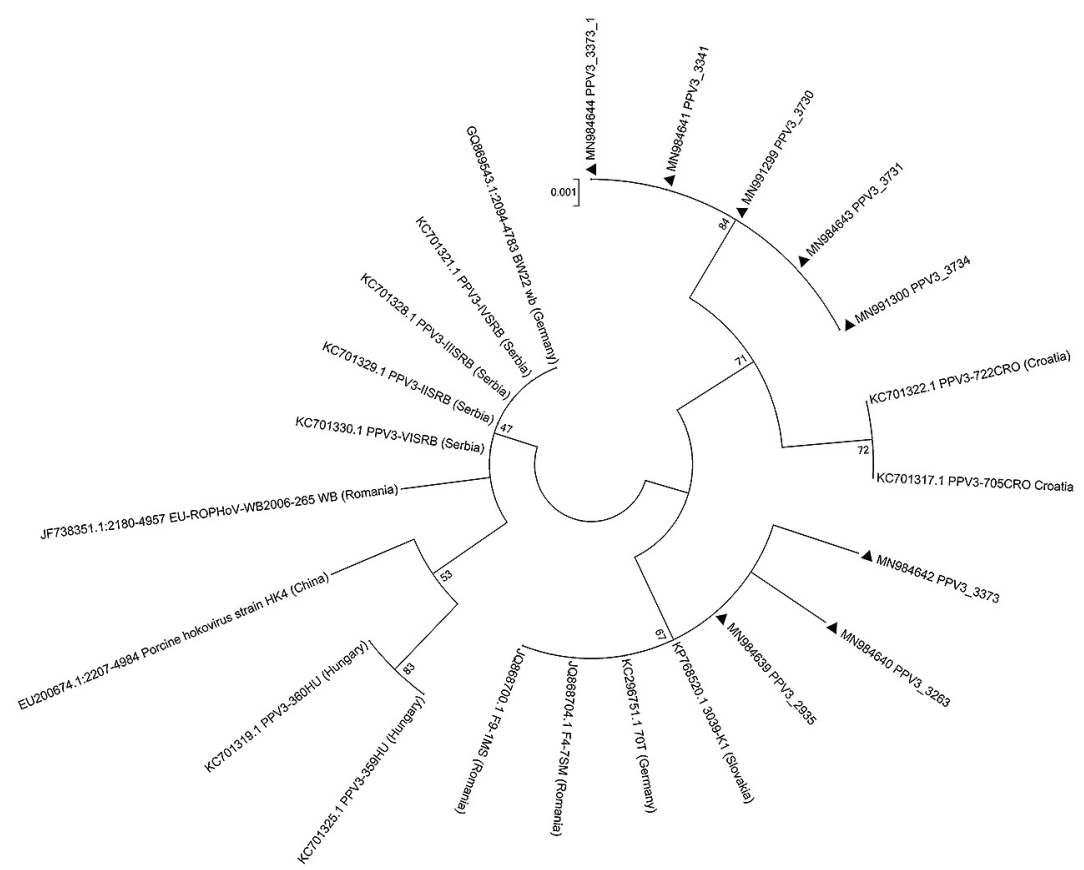

Figure 4. Phylogenetic tree constructed from 322 long partial VP1 gene nucleotide sequences of wild boar PPV3 strains and reference PPV3 strains obtained from NCBI GenBank. The tree was constructed using Maximum Likelihood algorithm with 1000 bootstrap replicates (using MEGA version 7). Black triangles indicate the selected Serbian wild boar sequences.

other authors significantly differ from ours. The detection rate of PPV1 in organ samples from 842 shot free-living wild boars during the 2006-2011 hunting seasons in Romania was 5.2\% [21]. A more recent examination was conducted in Serbia on 40 samples of spleen, kidney, tonsils, and blood from wild boars hunted about 80 $\mathrm{km}$ south from the sampling locations in our study and separated by the Danube river. Interestingly, none of the samples examined in this study were positive for the presence of PPV1 [24].

The positive rate of $21.7 \%$ for PPV2 determined in this study was relative to the results obtained in studies concerning domestic pigs in Poland, Africa and the USA $[8,11,29]$. However, investigations concerning PPV2 positive rates in the samples from wild boars are scarce. Anti-PPV2 antibodies were found in $61.1 \%$ of the examined wild boar sera, although the detection of this virus in organ samples was not performed [24].

Porcine parvovirus 3 was most commonly detected amongst all positive samples with the detection rate of $69.6 \%$. Since its discovery in 2008 and genetic relatedness with human parvoviruses, PPV3 is the subject of interest in an increasing number of publications $[8,9,14,15,20,25]$. Two wild boar studies showed lower PPV3 positive rates compared to our examination. An investigation conducted in Portugal confirmed 
PPV3 in 24\% of wild boar liver and sera samples [15]. Similarly, a positive rate for PPV3 of $32.7 \%$ was detected in liver and sera samples of wild boars in Germany [25]. Interestingly, the increasing prevalence of PPV3 positive wild boars was recorded over a period of 5 years [20].

Porcine parvovirus 4 DNA was not detected in any of the examined samples from wild boars in this study. Comparably, low PPV4 prevalence of $0.95 \%$ was noted in wild boars and similar studies concerning these animals are limited and mostly concern phylogenetic analysis [5,8-10,11,16,27,28].

Available studies analyze the presence of porcine parvoviruses in different organ samples from both domestic pigs and wild boars, still, the ones concerning domestic pigs are more abundant [5,10,23,24,28,30]. Porcine parvovirus 2 and PPV3 DNA were discovered in a total of $9 \%$ pig liver, kidney, spleen and lymph node samples [10]. At the same time, substantially higher PPV3 prevalence in different organs of the Chinese domestic pig was detected [30]. The increasing PPV3 positive rates in liver and blood serum samples of wild boars were also confirmed [25]. Lymph nodes, spleen, and tonsils of wild boars from Romania were mostly positive for the presence of PPV3 in up to $50.54 \%$ of the samples, with PPV1 being less common $(5.2 \%)[10,20]$. Similarly, in our study, PPV3 was most frequently detected in all the examined organ samples, however, it was accompanied by high detection rates of PPV1. Moreover, spleen and tonsil samples from wild boars in a previous study in Serbia were negative for the presence of PPV1 [23]. Our study showed the presence of PPV1 and PPV3 DNA in most of the PPV positive tonsil samples, whilst PPV2 was less prevalent. Out of all positive organ samples in this research, co-infections with two or three PPVs were a very common finding in the organs of wild boars. The presence of co-infections with more than three PPVs in domestic pigs was discovered in over $60 \%$ of tonsil samples in a study from Thailand [27]. Furthermore, high rates of mixed PPV infections were also reported in the tonsils from domestic pigs in Germany [28].

The results of the sequence analysis of partial NS1 gene of wild boar PPV1 strains from Serbia revealed that they were 99 to $100 \%$ similar amongst each other including European and US domestic pig strains. Similarly, in another study concerning wild boars in Romania, the overall nucleotide homology for PPV1 excluding the partial VP1/VP2 sequences, ranged from 98.8 to $99.9 \%$ [21]. However, this may be due to the limited region of the genome examined in our study which is considered to be conserved. Similarly, to our phylogenetic results, the South African PPV1 sequences grouped in one clade with virulent Kresse strain and other reference sequences, whilst the NADL-2 strains formed a separate cluster [8].

The VP1 coding region of porcine parvovirus 2 is suitable for genomic characterization studies [31]. Partial VP1 gene sequences of wild boar PPV2 strains from Serbia showed high sequence similarities with each other that ranged from 98 to $100 \%$. Similarly, high PPV2 sequence homogeneity was reported for Hungarian, German, South African, and the US strains ranging from 93 to $100 \%$ [8,10,28,29]. However, 
nucleotide differences of up to $11.2 \%$ were described in the study of PPV2 sequences from Thailand [27]. Wild boar PPV2 strains in this srudy were also 98 to 100\% similar with other domestic pig strains from Serbia and surrounding European countries including Croatia and Hungary, as well as with a wild boar PPV2 strain from Romania. However, the previously reported nucleotide similarity levels of PPV2 strains from wild boars and domestic pigs were 93.7-98.4\%, whilst they ranged from 93.9 to $96.8 \%$ in comparison with sequences from other countries [5]. The sequences of PPV2 strains detected in Hungary and Germany showed 94-99\% homogeneity when compared to other analogous GenBank sequences $[10,28]$. In correlation with strains from China, Brazil, and the USA, the identities of Serbian wild boar PPV2 sequences ranged from 97 to $98 \%$. The persistent evolution of PPV2 strains from the USA was pointed out reporting their similarities of $95.4-97.7 \%$ with strains from China and 94.7\% with the original PPV2 reference strain discovered in Myanmar [29]. However, the studied Serbian strains shared 97 to $98 \%$ similarity with the mentioned Myanmar strain. The wild boar PPV2 sequences from our study had the most differences when analyzed with analogous sequences from South African domestic pigs (94 to 97\%) [8]. Correspondingly, the variations from 91.9 to $97.5 \%$ were noted comparing South African PPV2 strains with other strains available in GenBank [8]. On the phylogenetic tree, Serbian wild boar PPV2 sequences clustered with wild boar and domestic pig strains from Serbia, Croatia, Hungary, Romania, and with the original strain from Myanmar. However, none of the Serbian sequences analyzed in this study clustered with the PPV2 sequences from Brazil, China, USA, and South Africa. Similarly, one part of the Hungarian PPV2 sequences grouped with the original PPV2 from Myanmar, whilst others grouped separately with the sequences from China [10]. In further support of our results, the PPV2 sequences from South Africa clustered separately with PPV2 reference sequences from China and Japan, and apart from the original PPV2 strain H-1 from Myanmar [8]. Corresponding results were also obtained in studies from Romania, China, and Thailand [5,27,30].

\section{Serbian wild boar porcine parvovirus 3 partia}

1 VP1 sequences were 99 to 100\% similar to each other, as well as to domestic pig strains from Croatia, Romania, and Germany, and also to a wild boar strain from Slovakia. German wild boar PPV3 sequences are closely related showing 99.1\% identity, whilst a difference of 1.8-2.3\% was noted in correlation to the isolates from Hong Kong [25]. However, the PPV3 strains obtained from the samples of Romanian wild boars from the hunting season 2006/2007 showed a close relationship to PPV3s from German wild boars, whilst the PPV3s from season 2010/2011 were mostly similar to strains from Hong Kong [20]. The wild boar PPV3 sequences in our study were 1 to $2 \%$ different from the above mentioned wild boar strains from Germany and Romania, as well as from domestic pig strains from Hungary and Serbia. Similar VP1 sequence divergence was reported in the examination of partial VP1 sequences of PPV3 strains isolated from wild boars in Portugal [15]. Phylogenetic analysis of eight selected Serbian wild 
boar PPV3 strains demonstrated clustering with domestic pig strains from Croatia, Romania, and Germany, and a wild boar strain from Slovakia. The analysis of German PPV3 strains from domestic pigs revealed the existence of two clades named A and $\mathrm{B}$, and the sequence 70T (KC296751) belonged to clade A along with some of the analogous Romanian domestic pig PPV3 sequences (JQ868704 and JQ868700) [25]. Some of our PPV3 strains grouped with the above mentioned German and Romanian sequences from domestic pigs. However, the examined Serbian PPV3 strains clustered separately from German and Romanian wild boar strains, domestic pig strains from Hungary and Serbia, as well as from the original porcine hokovirus strain. In support of our results, wild boar PPV3 sequences from Germany and Romania were previously appointed to clade B [28].

This investigation aimed to describe the presence of different porcine parvoviruses in the samples originating from wild boars in Serbia for the first time, as well as to elucidate their phylogenetic relationships and prevalence in sampled tissues. The highest percentage of lymph nodes were positive, followed by spleen samples and tonsils, however, virus prevalence in individual organ samples was variable, with frequent detection of co-infections, which demonstrates the equal importance and suitability of all of the samples used for this type of examination. No significant nucleotide differences were found in the NS1 genes of analyzed wild boar PPV1 strains since this region is conserved and is more suitable as a target area for the studies of PPV1 prevalence. The VP1 coding region of porcine parvoviruses 2 and 3 proved to be appropriate for genomic characterization of wild boar strains of the corresponding viruses. Porcine parvovirus 2 strains from Serbia were more variable in comparison with analogous PPV2 sequences from different parts of the world which may imply the existence of a certain geographical distribution of genetically diverse PPV2 strains. Serbian wild boar porcine parvovirus 3 partial VP1 sequences clustered separately from most of the analyzed wild boar PPV3s, the strains from Serbian domestic pigs, and the original porcine hokovirus strain. This may indicate that genetically different PPV3 strains circulate amongst Serbian domestic pigs and wild boars. Furthermore, despite the high level of homology which implies its genetic stability, PPV3 should be thoroughly analyzed in both domestic and wild animals in the view of its analogy with human parvoviruses.

To this day, there has been no proof of the clinical significance of novel parvoviruses, and their high prevalence in healthy animals may imply their ubiquitous nature. However, wild boars represent very interesting models for further investigations since wildlife represents a potential reservoir for the spread of genetically altered strains of known viruses. Moreover, these animals are suitable for studies in the field of molecular epidemiology. Examinations should also be conducted to elucidate the transmission patterns of different porcine parvoviruses, potential effects on each other in infected animals, as well as possible pathological implications of PPV infection. 


\section{Acknowledgments}

The study was supported by the Ministry of Education, Science and Technological Development of the Republic of Serbia (Contract number 451-03-68/202014/200143).

\section{Authors' contributions}

JN, AR, and AK carried out the molecular genetic studies, participated in the sequence alignment and drafted the manuscript. AR, BT, DB participated in the sequence alignment. DK, MR, and SO participated in the design of the study and performed the statistical analysis. AŽ and MĆ collected samples for analysis. NM, DM, AŽ conceived the study, and participated in its design and coordination and helped to draft the manuscript. All authors read and approved the final manuscript.

\section{Declaration of conflicting interests}

The author(s) declared no potential conflicts of interest with respect to the research, authorship, and/or publication of this article.

\section{REFERENCES}

1. Cotmore SF, Agbandje-McKenna M, Canuti M, Chiorini JA, Eis-Hubinger A, Hughes J, Mietzsch M, Modha S, Ogliastro M, Pénzes JJ, Pintel DJ, Qiu J, Soderlund-Venermo M, Tattersall P, Tijssen P, ICTV Report Consortium: ICTV Virus Taxonomy Profile: Parvoviridae. J Gen Virol 2019, 100:367-368.

2. Parrish CR: Chapter 12-Parvoviridae. In: Fenner's Veterinary Virology. 5th ed. Academic Press; 2017, 245-257.

3. Truyen U, Streck AF: Parvoviruses. In: Diseases of Swine. 11th ed. Wiley-Blackwell; 2019, 611-621.

4. Gonzalez-Barrio D, Martin-Hernando MP, Ruiz-Fons F: Shedding patterns of endemic Eurasian wild boar (Sus scrofa) pathogens. Res Vet Sci 2015, 102:206-211.

5. Cadar D, Csagola A, Kiss T, Tuboly T: Capsid protein evolution and comparative phylogeny of novel porcine parvoviruses. Mol Phylogenet Evol 2013, 66:243-253.

6. Milek D, Wozniak A, Guzowska M, Stadejek T: Detection Patterns of Porcine Parvovirus (PPV) and Novel Porcine Parvoviruses 2 through 6 (PPV2-PPV6) in Polish Swine Farms. Viruses 2019, 11:474.

7. Streck AF, Canal CW, Truyen U: Molecular epidemiology and evolution of porcine parvoviruses. Infect Genet Evol 2015, 36:300-306.

8. Afolabi KO, Iweriebor BC, Obi LC, Okoh AI: Prevalence of porcine parvoviruses in some South African swine herds with background of porcine circovirus type 2 infection. Acta Trop 2019, 190:37-44.

9. Cadar D, Lorincz M, Kiss T, Novosel D, Podgorska K, Becskei Z, Tuboly T, Csagola A: Emerging novel porcine parvoviruses in Europe: origin, evolution, phylodynamics and phylogeography. J Gen Virol 2013, 94:2330-2337. 
10. Csagola A, Lorincz M, Cadar D, Tombacz K, Biksi I, Tuboly T: Detection, prevalence and analysis of emerging porcine parvovirus infections. Arch Virol 2012, 157:1003-1010.

11. Cui J, Biernacka K, Fan J, Gerber PF, Stadejek T, Opriessnig T: Circulation of Porcine Parvovirus Types 1 through 6 in Serum Samples Obtained from Six Commercial Polish Pig Farms. Transbound Emerg Dis 2017, 64:1945-1952.

12. Hijikata M, Abe K, Win KM, Shimizu YK, Keicho N, Yoshikura H: Identification of new parvovirus DNA sequence in swine sera from Myanmar. Jpn J Infect Dis 2001, 54:244-245.

13. Cheung AK, Wu G, Wang D, Bayles DO, Lager KM, Vincent AL: Identification and molecular cloning of a novel porcine parvovirus. Arch Virol 2010, 155:801-806.

14. Lau SKP, Woo PCY, Tse H, Fu CTY, Au WK, Chen, XC, Tsoi HW, Tsang THF, Chan JSY, Tsang DNC, Li KSM, Tse CWS, Ng TK, Tsang OTY, Zheng BJ, Tam S, Chan KH, Zhou B, Yuen KY: Identification of novel porcine and bovine parvoviruses closely related to human parvovirus 4. J Gen Virol 2008, 89:1840-1848.

15. Miranda C, Coelho C, Vieira-Pinto M, Thompson G: Porcine hokovirus in wild boar in Portugal. Arch Virol 2016, 161:981-984.

16. Opriessnig T, Xiao CT, Gerber PF, Halbur PG: Identification of recently described porcine parvoviruses in archived North American samples from 1996 and association with porcine circovirus associated disease. Vet Microbiol 2014:173:9-16.

17. Cadar D, Csagola A, Lorincz M, Tombacz K, Spinu M, Tuboly T: Distribution and genetic diversity of porcine hokovirus in wild boars. Arch Virol 2011, 156:2233-2239.

18. Xiao CT, Halbur PG, Opriessnig T: Complete genome sequence of a novel porcine parvovirus (PPV) provisionally designated PPV5. Gen Announc 2013, 1 (e00021-12).

19. Ni J, Qiao C, Han X, Han T, Kang W, Zi Z, Cao ., Zhai X, Cai X: Identification and genomic characterization of a novel porcine parvovirus (PPV6) in China. Virol. J 2014, 11: 203.

20. Palinski RM, Mitra N, Hause BM: Discovery of a novel Parvovirinae virus, porcine parvovirus 7, by metagenomic sequencing of porcine rectal swabs. Virus Genes 2016, 52: 564-567.

21. Cadar D, Dan A, Tombacz K, Lorincz M, Kiss T, Becskei Z, Spinu M, Tuboly T, Csagola A: Phylogeny and evolutionary genetics of porcine parvovirus in wild boars. Infect Genet Evol 2012, 12:1163-1171.

22. Lukač B, Knežević A, Milić N, Krnjaić D, Veljović Lj, Milićević V, Zorić A, Đurić S, Stanojević M, Nišavić J: Molecular Detection of PCV2 And PPV in Pigs in Republic of Srpska, Bosnia and Herzegovina. Acta Vet-Beograd 2016, 66: 51-60.

23. Miković R, Knežević A, Milić N, Krnjaić D, Radojičić M, Veljović Lj, Milićević V, Zorić A, Stanojević M, Nišavić J: Molecular Detection of Pseudorabies Virus (PRV), Porcine Parvovirus (PPV) and Porcine Circovirus 2 (PCV2) in Swine in Republic of Montenegro. Acta Vet-Beograd 2016, 66: 347-358.

24. Milicevic V, Radojicic S, Valcic M, Ivovic V, Radosavljevic V: Evidence of Aujeszky's disease in wild boar in Serbia. BMC Vet Res 2016, 12:134.

25. Adlhoch C, Kaiser M, Ellerbrok H, Pauli G: High prevalence of porcine Hokovirus in German wild boar populations. Virol J 2010, 7:171.

26. Soares RM, Durigon EL, Bersano JG, Richtzenhain LJ: Detection of porcine parvovirus DNA by the polymerase chain reaction assay using primers to the highly conserved nonstructural protein gene, NS-1. J Virol Methods 1999, 78:191-198.

27. Saekhow P, Ikeda H: Prevalence and genomic characterization of porcine parvoviruses detected in Chiangmai area of Thailand in 2011. Microbiol Immunol 2015, 59:82-88. 
28. Streck AF, Homeier T, Foerster T, Fischer S, Truyen U: Analysis of porcine parvoviruses in tonsils and hearts from healthy pigs reveals high prevalence and genetic diversity in Germany. Arch Virol 2013, 158:1173-1180.

29. Xiao CT, Gerber PF, Gimenez-Lirola LG, Halbur PG, Opriessnig T: Characterization of porcine parvovirus type 2 (PPV2) which is highly prevalent in the USA. Vet. Microbiol 2013, 161:325-330.

30. Sun J, Huang L, Wei Y, Wang Y, Chen D, Du W, Wu H, Liu C: Prevalence of emerging porcine parvoviruses and their co-infections with porcine circovirus type 2 in China. Arch Virol 2015, 160:1339-1344.

31. Saekhow P, Mawatari T, Ikeda H: Coexistence of multiple strains of porcine parvovirus 2 in pig farms. Microbiol Immunol 2014, 58:382-387.

\title{
GENETSKA ANALIZA I DISTRIBUCIJA PARVOVIRUSA (PPVs) DETEKTOVANIH U ORGANIMA DIVLJIH SVINJA U SRBIJI
}

\author{
NIŠAVIĆ Jakov, MILIĆ Nenad, RADALJ Andrea, KRNJAIĆ Dejan, \\ MILIĆEVIĆ Dragan, KNEŽEVIĆ Aleksandra, RADOJIČIĆ Marina, \\ OBRENOVIĆ Sonja, ĆOSIĆ Milivoje, TEŠOVIĆ Bojana, BENKOVIĆ Damir, \\ ŽIVULJ Aleksandar
}

Parvovirusi svinja predstavljaju genetski različite viruse koji izazivaju infekcije domaćih i divljih svinja. Parvovirus svinja 1 (PPV1) dovodi do pojave reproduktivnih problema kod odraslih jedinki, dok klinički značaj PPV2, PPV3 i PPV4 još uvek nije u potpunosti razjašnjen. Izvršena je detekcija i analiza genetskih sekvenci parvovirusa koji cirkulišu u populaciji divljih svinja u Srbiji u cilju njihove filogenetske analize i određivanja zastupljenosti u ukupno 122 uzorka organa prikupljenih tokom 2018. godine. Prisustvo DNK PPV1, PPV2 i PPV3 detektovano je u 56,6\% ispitanih uzoraka, pri čemu prisustvo PPV4 nije utvrđeno. Među pozitivnim uzorcima, PPV3 je procentualno najzastupljeniji virus detektovan u 69,6\%, dok je prisustvo PPV1 i PPV2 utvrđeno u $63,8 \%$, odnosno u $21,7 \%$ pozitivnih uzoraka. Infekcije jednim virusom su češće identifikovane, međutim, prisustvo mešovitih infekcija sa dva, odnosno tri parvovirusa zabeleženo je u 34,8\% i 10,1\% uzoraka. Analizom genetskih sekvenci PPV1 detektovanih kod divljih svinja nisu utvrđene značajnije razlike u odnosu na analogne sekvence PPV1 poreklom od domaćih svinja iz Evrope i SAD, međutim zabeleženo je izdvajanje u zaseban klaster u odnosu na kineske sojeve virusa i soj NADL-2. Ispitivanjem sekvenci PPV2 utvrđena je izvesna geografska distribucija genetski različitih sojeva navedenog virusa s obzirom na njihovu veliku sličnost sa sojevima virusa iz susednih zemalja. Sekvence PPV3 detektovanih kod divljih svinja su se na filogenetskom stablu izdvajale u zaseban klaster u odnosu na većinu dostupnih sekvenci navedenog virusa detektovanih kod divljih svinja. Pored toga, zabeleženo je da genetski različiti sojevi PPV3 cirkulišu u populacijama divljih i domaćih svinja u Srbiji. 